\title{
A ESPACIALIDADE RURAL DAS RESERVAS PARTICULARES DO PATRIMÔNIO NATURAL (RPPN) NO ESTADO DO RIO DE JANEIRO
}

\author{
RURAL SPACIALITY OF PRIVATE RESERVES OF NATURAL PATRIMONY (RPPN) IN THE STATE OF RIO DE JANEIRO
}

\section{RESUMO}

Desde a Eco-92, diferentes dispositivos regulatórios, alinhados a emergentes diretrizes de ordenamento territorial e ambiental, foram elaborados para disciplinar os usos da terra no espaço rural nacional, com repercussões específicas em cada unidade da federação. Nesse contexto, o presente trabalho analisou as dinâmicas territoriais responsáveis pela expansão de Reservas Particulares do Patrimônio Natural (RPPN) no estado do Rio de Janeiro. As redefinições paisagísticas derivaram de práticas espaciais indicativas de novas territorialidades, (re)funcionalizações e ressignificações do espaço rural fluminense. Enfoques metodológicos qualitativo e misto foram adotados para a interpretação de dados secundários e primários, estes últimos recolhidos em campo a partir de uma amostra de cinquenta proprietários rurais. Os resultados desenrolaram uma trama de intencionalidades e compensações responsáveis por mudanças nos mosaicos regionais de uso e cobertura da terra, tais como: o incremento de áreas florestais para preservação, apreciação paisagística e remuneração por serviços ambientais. O crescimento de unidades de conservação privadas foi favorecido por conjunturas sócio-políticas a partir das quais identificamos uma particular densidade institucional de processos territorializantes, representados pela permeabilidade de projetos, programas - ICMS Verde, Produtor de Águas e Florestas, Conexão Mata Atlântica, Rio Rural, Programa de Incentivo às RPPNs - e agentes institucionais direta ou indiretamente envolvidos - APN/RJ, SERPPN, ICMBio, AMLD e outros - na difusão da referida categoria de área protegida, incentivando, portanto, novos caminhos para o desenvolvimento e a sustentabilidade rural. Palavras-chave: Geografia; Território; Paisagem; Ruralidade; Reserva Particular do Patrimônio Natural (RPPN).

Palavras-chave: Geografia; Território; Paisagem; Ruralidade; Reserva Particular do Patrimônio Natural (RPPN).

\section{ABSTRACT}

Since the United Nations Conference on Environment and Development, different regulatory mechanisms, in line with emerging territorial and environmental planning guidelines, have been developed to discipline land uses in the national countryside, with specific repercussions on each unit of the brazilian federation. In this context, the present work analyzed the territorial dynamics responsible for the expansion of Private Reserves of Natural Patrimony (RPPN) in the Rio de Janeiro state. The landscape redefinitions were derived from spatial practices indicative of new territorialities, (re) functionalisations and re-significances of the countryside. Qualitative and mixed methodological approaches were adopted for the interpretation of secondary and primary data, collected from a sample of fifty rural landowners. The results identified a network of intentionalities and compensations responsible for changes in the regional mosaics of land use and coverage, such as: the increase of forest areas for preservation, landscape appreciation and remuneration for environmental services. The growth of private conservation units was favored by socio-political conjunctures from which we identified a particular institutional density of territorial processes, represented by the permeability of projects, programs - ICMS Ecológico, Produtor de Águas e Florestas, Conexão Mata Atlântica, Rio Rural, Programa de Incentivo às RPPN - and agents directly or indirectly involved - APN / RJ, SERPPN, ICMBio, AMLD - in the diffusion of this category of protected area, encouraging new paths for development and rural sustainability. Keywords: Territory; Landscape; Rurality; Private Reserve of the Natural Patrimony (RPPN).

Keywords: Territory; Landscape; Rurality; Private Reserve of the Natural Patrimony (RPPN).

\section{Elton Simões Gonçalves a, b}

a Instituto Federal de Educação, Ciência e Tecnologia do Rio de Janeiro (IFRJ), Rio de Janeiro, RJ, Brasil

${ }^{\text {b }}$ Fundação de Apoio à Escola Técnica (FAETEC), Rio de Janeiro, RJ, Brasil

DOI: 10.12957/geouerj.2020.47275

Correpondência: eltongeosg@gmail.com

Recebido em: 16 set. 2019

Revisado em: 23 out. 2019

Aceito em: 14 dez.2019

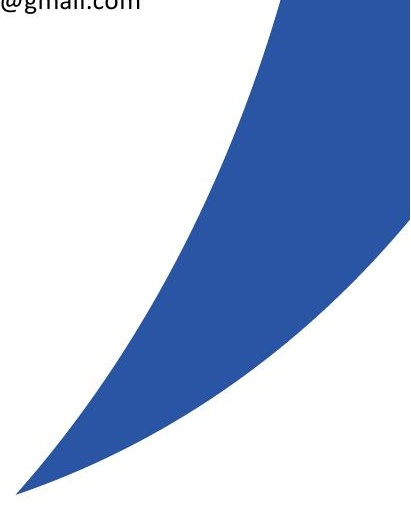




\section{INTRODUÇÃO}

A emergência do rural contemporâneo enquanto locus promotor de serviços e externalidades ambientais inaugura um extenso debate sobre iniciativas de conservação e preservação da biodiversidade no interior de propriedades privadas. Novos interesses, atores e relações interescalares se refletem em ordenamentos territoriais emergentes, os quais requerem matrizes analíticas atentas a uma diversidade socioespacial produtora e renovadora de paisagens. A arena política que deriva dessa conjuntura repercute em normatizações com a finalidade de disciplinar os usos dos territórios à luz de referenciais técnicos de corte ecológico, tais como: incrementar a conectividade entre fragmentos florestais de particulares e unidades de conservação públicas; potencializar a dispersão de polinizadores; proteger mananciais, melhorar a qualidade dos recursos hídricos, dentre outros.

Nesse sentido, o objetivo do presente estudo consiste em analisar o quadro de crescimento das chamadas Reservas Particulares do Patrimônio Natural (RPPN) - modalidade de unidade de conservação integrante do Sistema Nacional de Unidades de Conservação (SNUC) - em atenção à potencialidade desses emergentes territórios como vetores de reestruturação rural no estado do Rio de Janeiro. O Decreto $\mathrm{n}$. 5.746/2006 definiu RPPN como "uma unidade de conservação de domínio privado, com o objetivo de conservar a diversidade biológica, gravada com perpetuidade, por intermédio do Termo de Compromisso, e averbada à margem de inscrição do Registro Público de Imóveis". (OJIDOS, 2018, p.44)

Argumenta-se que a espacialidade do evento em questão é sintomática de uma dinâmica territorial caracterizada pela crescente demanda de população urbana por áreas de lazer e/ou segunda residência, cuja aderência paisagística sinaliza para a reelaboração contínua da dualidade campo-cidade, engendrando novas ruralidades (CARNEIRO, 2012). O imaginário social da atual questão ambiental contribui para a releitura do mundo rural e modifica a percepção social do papel da agricultura, a qual mobiliza novos atores territoriais e resulta em demandas relacionadas a serviços ambientais e de lazer - tais como experiências turísticas, apreciação paisagística, gastronomia local e artigos artesanais.

\section{Caminho teórico-metodológico}

A geograficidade do fenômeno RPPN consiste em compreendê-lo como uma espacialidade de ordem sócio-normativa e ambiental, cujo padrão de distribuição atende a condicionantes locacionais e desenhos territoriais impulsionados pela atuação de atores interescalares. Para contemplar uma amostra representativa do objeto de estudo, a pesquisa priorizou áreas do estado do Rio de Janeiro com maior concentração de reservas, conforme é possível identificar na figura a seguir. 
Figura 1. Concentração espacial de Reservas Particulares do Patrimônio Natural no estado do Rio de Janeiro. Elaboração: GONÇALVES, 2019. Fonte: CNRPPN, 2018.

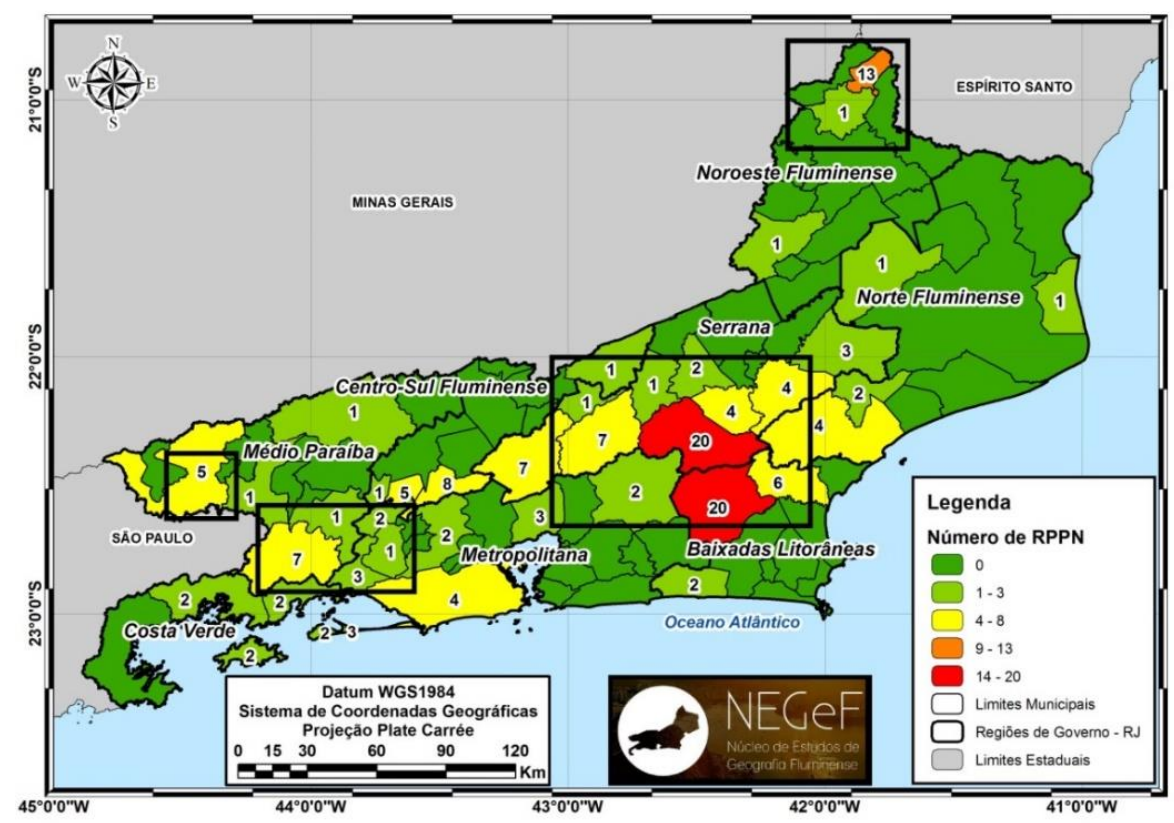

A Conferência das Nações Unidas sobre o Meio Ambiente e o Desenvolvimento de 1992 foi definida como o marco temporal para analisarmos a evolução do fenômeno RPPN até o ano 2018, uma vez que os documentos assinados no referido evento, como a Agenda 21 e a Convenção da Biodiversidade serviram de base para a elaboração de políticas voltadas para a criação e ampliação de inúmeras áreas ambientais protegidas, públicas e privadas.

Em atenção ao padrão de distribuição e concentração espacial das reservas particulares fluminenses, aliado à receptividade de proprietários predispostos a participar do estudo, a pesquisa de campo desenrolouse junto a cinquenta rppnnistas localizados nos municípios listados na figura 2 a seguir.

Figura 2. Percentual de propriedades pesquisadas por município no estado do Rio de Janeiro. Fonte: GONÇALVES, 2019.

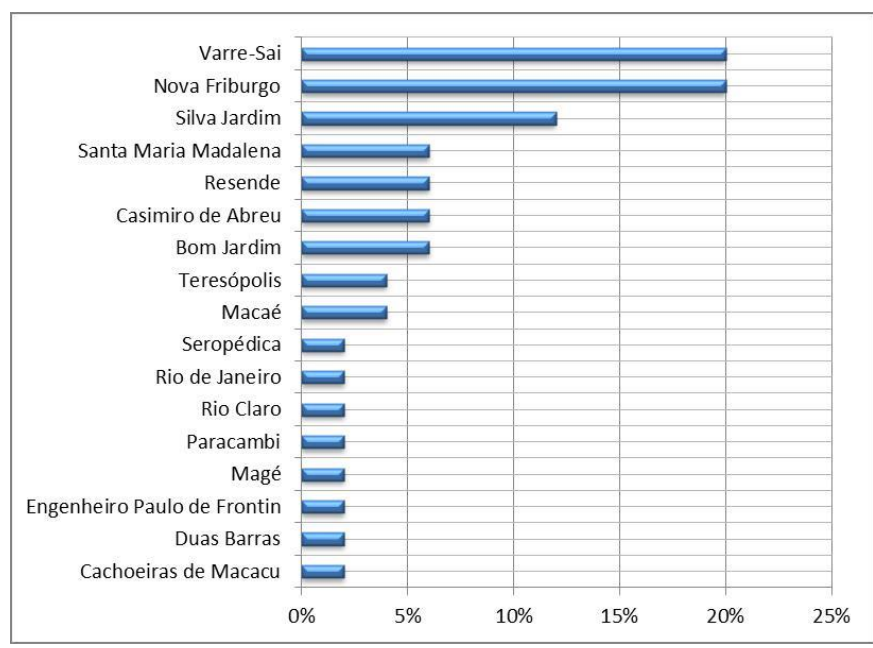


A amostragem correspondeu a um terço do universo e empregou uma abordagem qualitativa e mista para interpretação da dinâmica territorial e das tendências de evolução de cenários. O universo de atores selecionados também incluiu representantes de órgãos públicos responsáveis pela condução de programas institucionais incentivadores diretos ou indiretos do modelo.

Para a compreensão do modus operandi e vivendi dos atores rurais e suas relações com a fisionomia particular do arranjo espacial rural, destacamos os processos de territorialização institucionais (marcadas por relações verticais) e os diferentes graus de territorialidades autônomas - mas reativas aos primeiros - in situ (marcadas por relações horizontais). Em trabalho de campo, foram apreciadas as modalidades de manejo das RPPN e das formas de uso da terra circunscritas às mesmas. Além disso, também acompanhamos como observadores, com intervenções mínimas, o intercâmbio e as discussões pautadas pelos rppnistas em dois grupos fechados nas redes sociais, RPPN-RJ e RPPN Brasil. Nesses espaços acompanhamos a organização de encontros, fóruns e congressos voltados para a troca de inovações técnicas, de manejo e gestão.

\section{Das articulações multiescalares}

Conforme apontamos anteriormente, a Rio-92 é o marco temporal que inaugura a confluência do terceiro setor na assessoria e/ou condução de variados projetos, produzindo zoneamentos ambientais em diversas escalas. Como resultado, A UNESCO (Organização das Nações Unidas para a Educação, a Ciência e a Cultura) elevou a importância do bioma Mata Atlântica como Reserva da Biosfera através do Programa Mab (Man and Biosphere).

Aqui vale também destacar a contribuição da União Internacional para a Conservação da Natureza (UICN), ator global que influenciou de forma expressiva o desenho territorial e normativo das reservas particulares e de grande parte das categorias de unidades de conservação públicas que integram atualmente o Sistema Nacional de Unidades de Conservação. A Convenção da Diversidade Biológica, tratado internacional multilateral elaborado durante a Eco-92 também contou com a participação da UICN. Em nova rodada de debates durante a 10 a Conferência das Partes foram definidas as Metas de Aichi, cujo teor solicita explicitamente que a conservação em áreas privadas tenha um papel mais relevante.

Registrou-se, desde 1992, a atuação mais efetiva de ONGs internacionais e nacionais, tais como a Conservação Internacional Brasil, The Nature Conservancy (TNC), principalmente, a Fundação SOS Mata Atlântica para a condução de programas de incentivo às RPPNs, baseados na definição de corredores ecológicos que abrangeram o hotspot ambiental do bioma Mata Atlântica. O Fundo de Parceria para Ecossistemas Críticos (CEPF) viabilizou o financiamento do Programa de Incentivo às RPPNs (coordenado pela Aliança para a Mata Atlântica cuja participação contou com os três órgãos do terceiro setor citados 
anteriormente). Outras ONGs de expressão espacial mais localizada também contribuíram sensivelmente para a expansão das reservas particulares em nosso Estado, como é o caso das incursões promovidas pela Associação Mico-Leão-Dourado (AMLD) no limite entre as regiões de governo das Baixadas Litorâneas e Serrana.

Vale aqui também destacar a atuação pioneira da Associação Patrimônio Natural (APN) no trabalho de apoio a proprietários rurais na criação e gestão das reservas em parceria com O Instituto Brasileiro do Meio Ambiente e dos Recursos Naturais Renováveis (IBAMA), posteriormente representado pelo Instituto Chico Mendes de Conservação da Biodiversidade, e o Instituto Estadual do Ambiente (INEA). Portanto, o desenho operacional de corredores ecológicos resultantes buscou amortecer e favorecer a conectividade funcional dos fragmentos florestais até as áreas-núcleo do mosaico de uso e cobertura da terra, representados por unidades de conservação públicas de proteção integral, como parques e reservas biológicas. A materialização de tais iniciativas pode ser identificada na figura a seguir.

Figura 3. Áreas destinadas à gestão e/ou proteção da biodiversidade no estado do Rio de Janeiro. Elaboração: GONÇALVES, 2019. Fonte: INEA, MMA e AMLD, 2018.

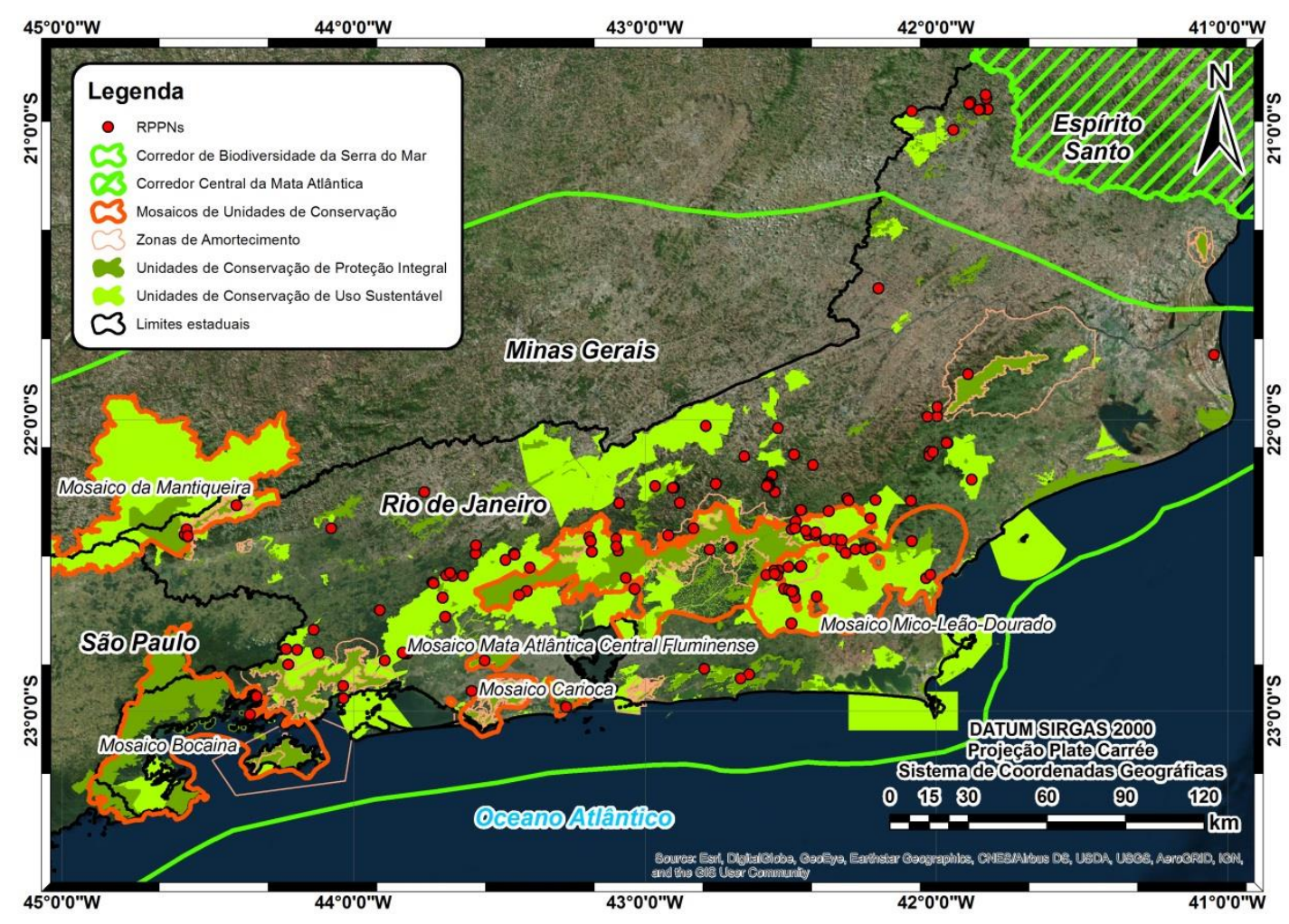

Com base nos dados disponíveis no Portal GeoINEA processados em SIG, o estado do Rio de Janeiro possui $27,5 \%$ da área continental coberto por unidades de conservação (UCS), 10,5\% destinados a UCs de 
categoria Proteção Integral e 20,5\% pertencente à categoria Uso Sustentável. 3,5\% correspondem à zona de sobreposição das duas categorias. No caso das RPPNs, 55\% se encontram inseridas nos limites de UCs de uso sustentável, apenas $5 \%$ cruzam UCs de proteção integral e em torno de $40 \%$ destas estão localizadas fora das UCs públicas, estejam predominantemente distribuídas na zona de amortecimento do modelo proposto pelo projeto Reserva da Biosfera da Mata Atlântica. Desse modo, as reservas particulares assumem o papel de "ilhas" de biodiversidade ou stepping stones, funcionando como refúgios de curto prazo para muitas espécies e funcionando a conectividade com fragmentos florestais maiores. As engenharias territoriais de viés ambiental até aqui citadas intercruzam no espaço rural se materializaram em corredores ecológicos (indutores de unidades de conservação e zonas de amortecimento) e nos chamados mosaicos (correspondentes ao espaço político composto por conselhos consultivos, nos quais os rppnistas possuem assento).

O arranjo espacial no qual as reservas particulares estão incluídas é permeado por relações sociais de pertencimento com a dimensão paisagística e territorial do campo. No âmbito do paradigma da multifuncionalidade rural, as questões incorporadas são as seguintes: segurança alimentar, proteção ambiental e valorização de sistemas extensivos de produção. Nesse sentido, as reservas privadas integram indiretamente o portfólio pós-produtivista. Apresentam-se, portanto, como arquiteturas territoriais que refuncionalizam os imóveis rurais para a provisão de serviços ambientais. A figura a seguir ilustra a sinalização de uma propriedade rural com RPPN reconhecida pelo órgão ambiental estadual.

Figura 4. Sinalização de RPPN existente em propriedade rural do município de Teresópolis/RJ. Fonte: GONÇALVES, 2019.

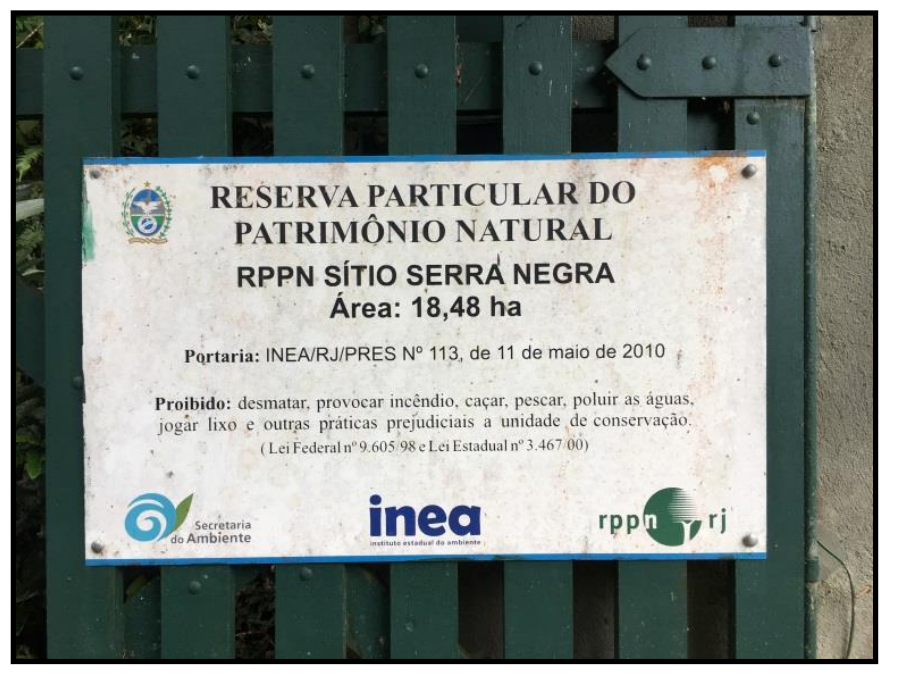

Outra linha de atuação do SERPPN (INEA) e da Associação Patrimônio Natural (APN-RJ) consiste em apoiar mecanismos de sustentabilidade financeira para as RPPNs através de políticas públicas direcionadas ao 
Pagamento por Serviços Ambientais (PSA), bem como a partir da sensibilização de prefeituras para o repasse de parcela do chamado ICMS ecológico a proprietários de RPPNs, dispositivo estadual que utiliza critérios ambientais para a determinação do quanto cada município vai receber pela repartição dos recursos financeiros arrecadados com o Imposto de Circulação do Imposto sobre Circulação de Mercadorias e Serviços (ICMS), correspondente a 2,5\% dos $25 \%$ de ICMS reservado para os municípios fluminenses. Como a existência de RPPNs é um critério que tende a aumentar a fatia do ICMS para os municípios, o entendimento é o de que as prefeituras possam impulsionar campanhas para incentivar a criação de novas reservas particulares e regulamentar, através de lei municipal, o percentual de repasse financeiro a proprietários com RPPN, situação em vigor apenas em dois municípios fluminenses: Varre-Sai e Rio Claro.

Quando situadas as RPPN no contexto da provisão dos chamados serviços ambientais, é pertinente ressaltar as vantagens de preservação florestal: regulação a vazão fluvial, aumento a capacidade de armazenamento nas bacias hidrográficas, redução da erosão laminar, diminuição dos impactos oriundos de inundações, conservação da biodiversidade, captura do carbono atmosférico, alternativas econômicas para a exploração sustentável da biota, educação e pesquisa científica, desfrute de belezas cênicas, turismo e lazer.

Pari passu à iniciativa do ICMS-E citada anteriormente, nos últimos anos, projetos voltados para a adequação ambiental de propriedades rurais com ou sem RPPNs, aqui representados pelo "Gerenciamento Integrado de Agroecossistemas em Microbacias Hidrográficas do Norte-Noroeste Fluminense - RIO RURAL/GEF" e "Desenvolvimento Rural Sustentável em Microbacias Hidrográficas do Estado do Rio de Janeiro - RIO RURAL/BIRD", foram empreendidos pela EMATER/RJ e contribuíram para a educação ambiental no campo. A iniciativa institucional em questão visou à promoção de práticas de manejo sustentável de recursos naturais com base na abordagem de manejo integrado de ecossistemas, utilizando a microbacia hidrográfica como unidade de planejamento - das comunidades agrícolas piloto, e se ampliou cinco anos depois, a partir do Projeto Rio Rural BIRD. As medidas práticas de adequação ambiental das propriedades rurais consistiram na proteção de nascentes (cercamento), recuperação (reflorestamento) de matas ciliares e áreas de recarga, instalação de fossas sépticas e de sistemas de tratamento nas localidades-alvo do projeto.

As iniciativas de pagamento por serviços ambientais devem ser entendidas como uma fonte adicional de renda ao proprietário rural, sendo uma forma de ressarcir os custos encarados pelas práticas conservacionistas que asseguram o fornecimento dos serviços ecossistêmicos. Para os programas do tipo PSA hídrico, as companhias de abastecimento e saneamento, os potenciais ganhos estão relacionados ao prolongamento da vida útil de suas plantas, em razão do aumento da oferta de água, bem como ganhos diretos ligados à redução dos custos de tratamento decorrente da melhoria da qualidade da água. As iniciativas de PSA florestal levam em consideração o aumento de estoques de carbono na paisagem agrícola, almejando a potencial inversão do processo de degradação das terras em ecossistemas críticos e únicos de importância 
global da Mata Atlântica. Além do ICMS ecológico citado anteriormente, sobressaem-se as seguintes iniciativas no estado do Rio de Janeiro: "Programa Produtor de Águas (Agência Nacional de Águas)", "Produtor de Águas e Florestas" (Instituto Terra de Preservação Ambiental) e "Conexão Mata Atlântica" (Ministério da Ciência, Tecnologia, Inovações e Comunicações).

Dois instrumentos de ordenamento ambiental dispostos na Lei 12.651/2012, o Cadastro Ambiental Rural (CAR) e Programa de Regularização Ambiental (PRA) também são incluídos aqui como componentes normativos que visam disciplinar e contribuir para a consequente adequação ambiental de propriedades rurais, que, por sua vez, podem estimular a criação de novas RPPNs. O CAR visa à localização e à situação de adequação ambiental de propriedades rurais, enquanto o PRA define as medidas de recuperação ambiental em propriedades com pendências apontadas pelo órgão estadual competente após análise no Sistema de Cadastro Ambiental Rural. Na prática, o CAR funciona como uma base de dados autodeclarados sobre as seguintes categorias espaciais em propriedades rurais: Área de Proteção Permanente (APP); Reserva Legal (ARL); Área de Uso Restrito (AUR); Área Rural Consolidada (ARC); remanescentes de vegetação nativa; áreas de interesse social e de utilidade pública (servidões administrativas). Dada a obrigatoriedade do CAR, duas situações podem estimular a expansão de RPPNs no estado do Rio de Janeiro: (1â) Uma vez permitida a sobreposição de uma futura reserva particular em extensões reservadas a Áreas de Preservação Permanente e de Reserva Legal, tais medidas restritivas podem induzir potenciais interessados a tomar conhecimento de projetos - coordenados por instituições públicas e do terceiro setor - de manejo e gestão em unidades de conservação privadas, favorecendo a inserção e a mobilização destes atores em novas redes institucionais visando à captação de recursos e compensações pela 'inutilização' de parcelas das propriedades; (2ª) no contexto em que um proprietário com déficit de reserva legal precise regularizar sua situação junto ao órgão ambiental, será possível o arrendamento de áreas de vegetação excedente em propriedades que atendam a essa condição, característica bastante comum em propriedades com RPPN. Tal cenário poderá estimular a criação de reservas privadas como forma de divulgar e diferenciar o ativo florestal a ser negociado. A figura 5 a seguir ilustra a soma da participação dos principais programas, projetos e atores institucionais citados anteriormente, que estão envolvidos no atual padrão de distribuição das RPPNs no estado do Rio de Janeiro. 
Figura 5. Representação dos vetores institucionais relacionados com a expansão de RPPNs no estado do Rio de Janeiro. Elaboração: GONÇALVES, 2019.

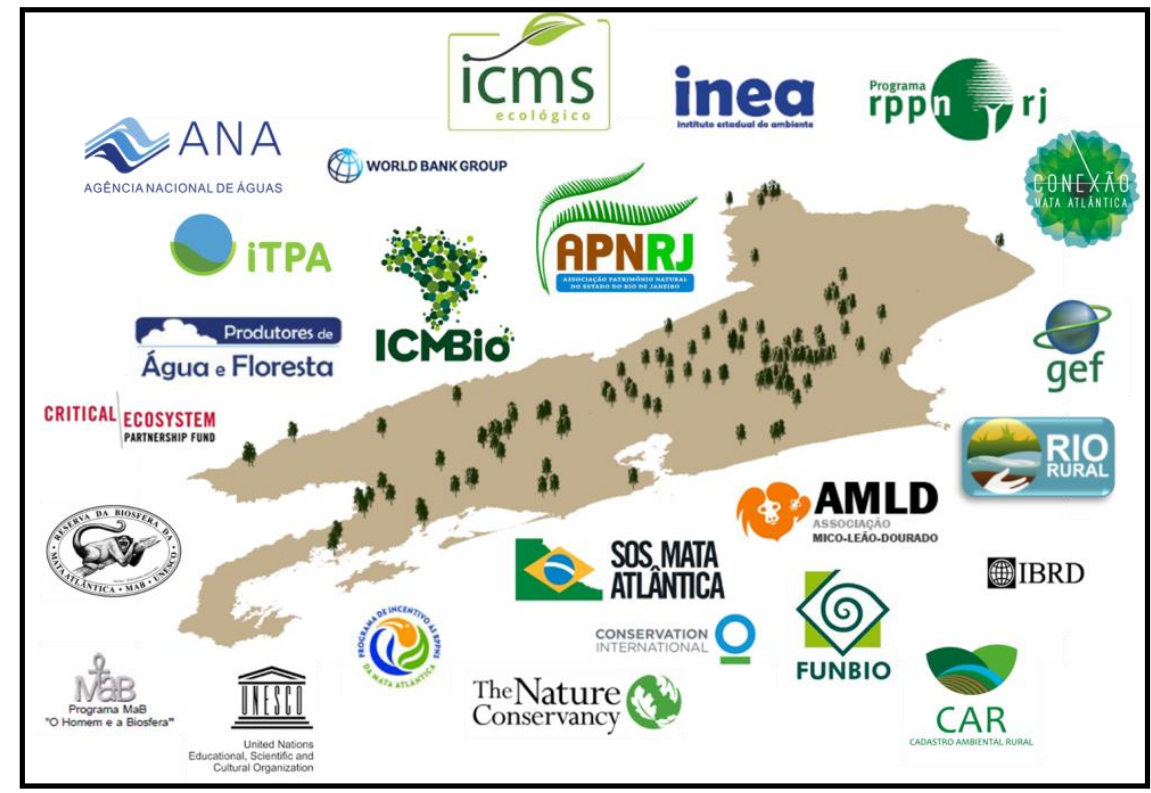

Somando 162 RPPNs desde o início dos anos 1990 - de acordo com informação obtida no Painel de Indicadores da Confederação Nacional de RPPNs em fevereiro de 2019-, o estado do Rio de Janeiro apresenta interstícios com desempenho variável que possuem relação direta com os arranjos e densidades institucionais decisivas na divulgação e no custeio total ou parcial de criação das unidades de conservação, cujo ápice ocorreu entre os anos 2001 e 2012. As figuras 6 e 7, disponíveis na página a seguir, detalham, respectivamente, a evolução da criação e o aumento da área protegida por RPPNs no território fluminense, atingindo a marca de $13.316,79$ hectares.

Ainda sobre o período, destacamos o Programa de Incentivo às RPPNs da Mata Atlântica, coordenado pela Fundação SOS Mata Atlântica, que contou com a participação da APN/RJ e da AMLD para viabilizar o reconhecimento de RPPNs federais e, posteriormente, estaduais. Foi também nesse período que se iniciou, efetivamente, as atividades do SERPPN-INEA, as quais contribuíram ainda mais para o expressivo crescimento de reservas particulares no Estado. Já o baixo desempenho, tanto na criação de novas reservas quanto do aumento de áreas protegidas no interstício 2013-2018, tem relação direta com a sucessão de arrestos impostos ao governo estadual para pagamento de dívidas, fato que reduziu drasticamente ou paralisou temporariamente as atividades do SERPPN, setor do INEA que vinha assumindo a demanda pela assistência e criação de novas RPPNs no estado. 
Figura 6. Criação de RPPNs no estado do Rio de Janeiro entre os anos 1990-2018. Elaboração: GONÇALVES, 2019. Fonte: CNRPPN, 2019.

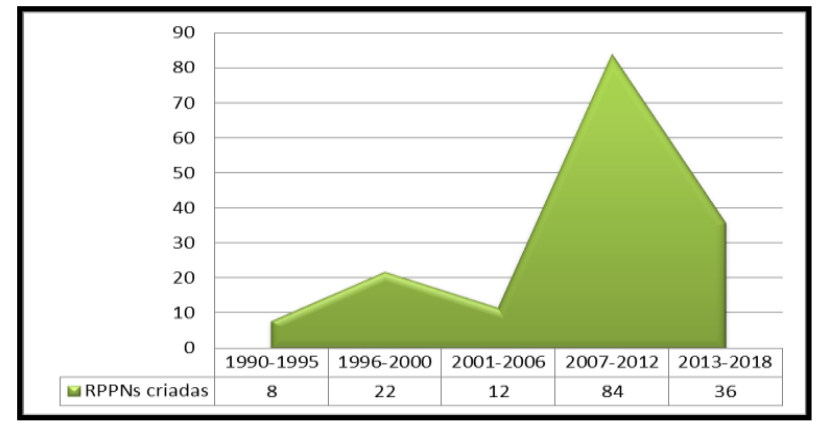

Figura 7. Variação da área florestal protegida em RPPNs entre os anos 1990 e 2018. Elaboração: GONÇALVES, 2019. Fonte: CNRPPN, 2019.

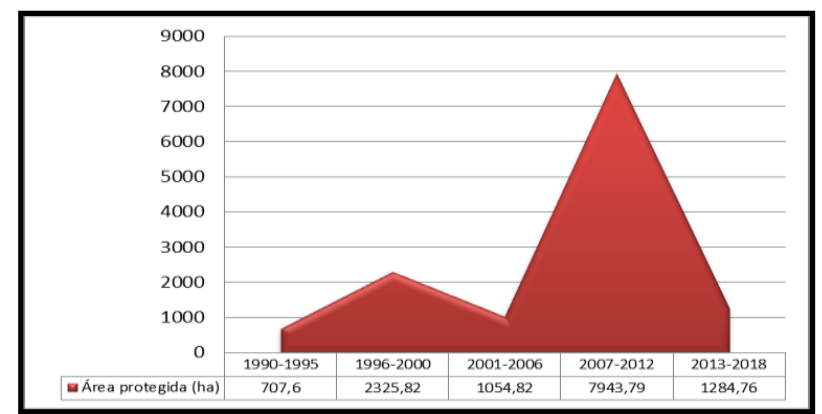

No entanto, ainda que a crise fiscal tenha abalado a rotina de trabalho do SERPPN, tal repartição se consolidou como a principal referência para viabilizar o reconhecimento e fomento a recursos para as RPPNs. Resultado de divulgações e organização de oficinas itinerantes pelo interior do estado, em pouco mais de dez anos, as portarias estaduais superaram o número de reservas federais, conforme podemos constatar na figura 8. As secretarias municipais de meio ambiente apresentam resultados ainda tímidos em função do engajamento recente, ou mesmo por conta da inexistência de legislação e corpo técnico específico para tal.

Figura 8. Reconhecimento de RPPNs por instâncias governamentais no estado do Rio de Janeiro. Elaboração: GONÇALVES, 2019. Fonte: CNRPPN, 2018.

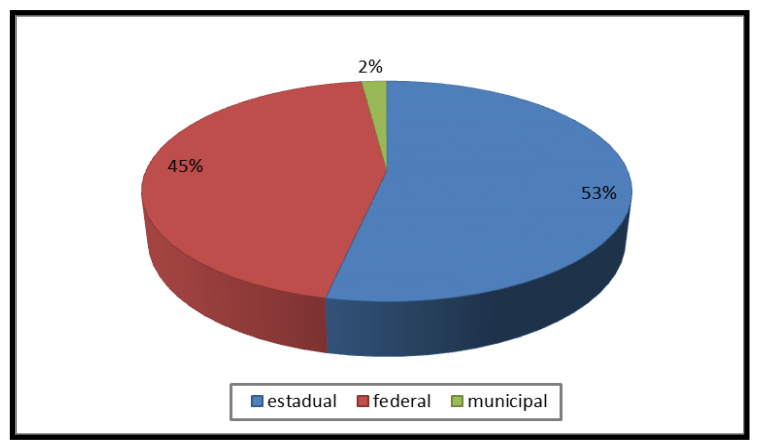


Os Rppnistas fluminenses: atores territoriais e produtores de paisagens

Os proprietários das reservas particulares fluminenses corresponde a um público composto predominantemente por pessoas físicas, seguido em percentual bem inferior, por pessoas jurídicas dos segundo e terceiro setores, conforme ilustrado na figura 9.

Figura 9. Tipos de proprietários de RPPN no estado do Rio de Janeiro. Elaboração: GONÇALVES, 2019. Fonte: CNRPPN, 2019.

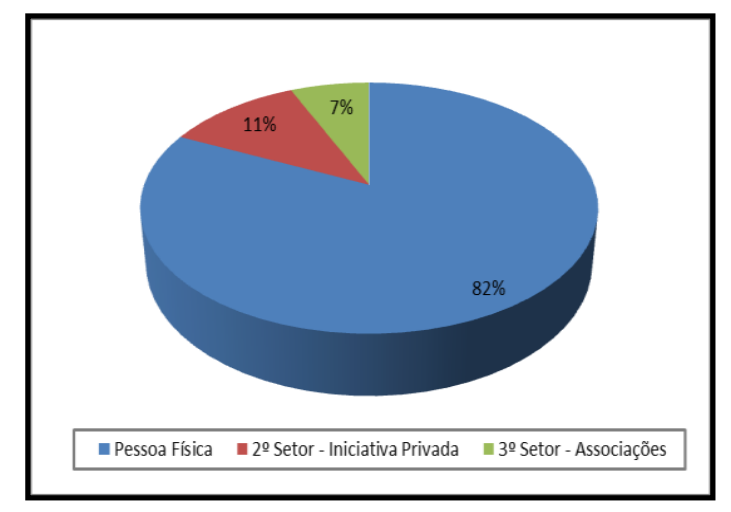

A figura 10, disponível a seguir, revela um padrão recente (2007-2018) de interiorização da expansão de reservas privadas, mais numeroso na região Serrana, nos limites desta com a região das Baixadas Litorâneas e aglomerados mais isolados nas demais regiões de governo.

Figura 10. Criação de RPPNs no estado do Rio de Janeiro por períodos. Elaboração: GONÇALVES, 2019. Fonte: CNRPPN, 2018.

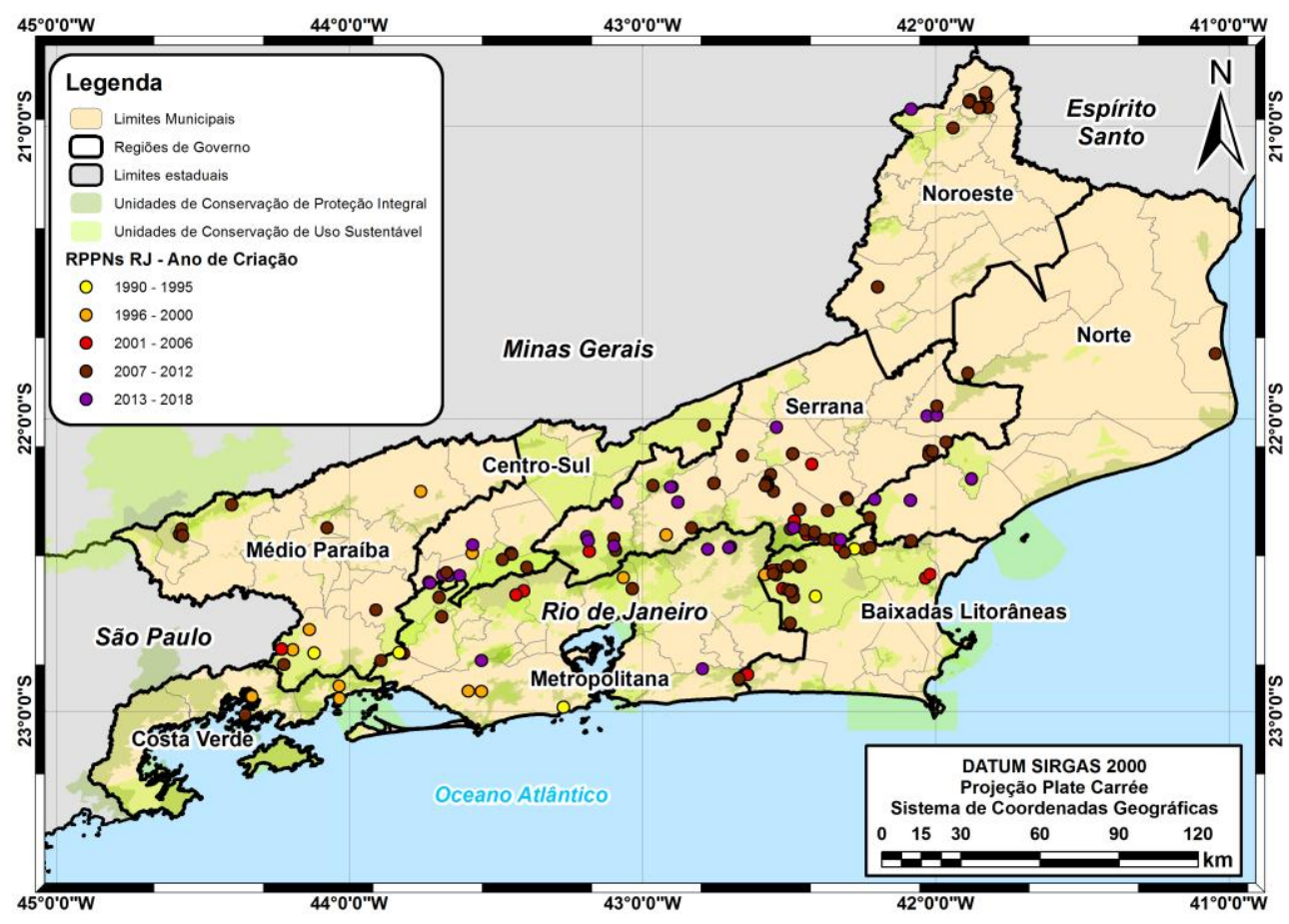


A pesquisa in loco, além de confirmar a predominância de pessoas físicas na condição de proprietárias das reservas, também acrescenta o fato de que 18\% das propriedades são fracionadas em cotas-parte, seja em função de heranças, ou associadas a modalidades condominiais. Nestes casos, a gestão da RPPN é compartilhada entre os responsáveis. Um padrão parecido também é observado na pequena participação das pessoas jurídicas, composta, conforme identificamos: por imobiliárias envolvidas no projeto de loteamentos, interessadas em disciplinar o uso do solo de entorno e na valoração paisagística - que inclui a preservação de amenidades ambientais em zonas residenciais de veraneio mais afastadas - ; e também pela atuação de ONGs vinculadas a projetos preservacionistas, a exemplo das RPPNs criadas recentemente pela Associação Mico Leão Dourado e a REGUA (Reserva Biológica de Guapiaçu).

Outra observação relevante tem a ver com o local de nascimento dos rppnistas entrevistados. O que nos chama a atenção na figura 116 é o fato de que $50 \%$ dos participantes da pesquisa se declararam nascidos e criados na capital do estado, informação essa que sustenta a ocorrência de um circuito urbano-rural paralelo à expansão de reservas particulares, que traz consigo concepções e valores preservacionistas notadamente construídos na cotidianidade citadina. O grupo representado por aqueles nascidos no local corresponde predominantemente a enclaves de produção agrícola em médias propriedades da região noroeste fluminense e imediações serranas mais afastadas dos centros urbanos, as quais incluem as RPPNs como potenciais fontes de recursos via repasse de ICMS ecológico ou Pagamento por Serviços Ambientais através do Programa Conexão Mata Atlântica. Nesse caso, a lógica da preservação compõe a diversificação de rendimentos nas propriedades rurais.

Figura 11. Local de nascimento dos informantes. Fonte: GONÇALVES, 2019.

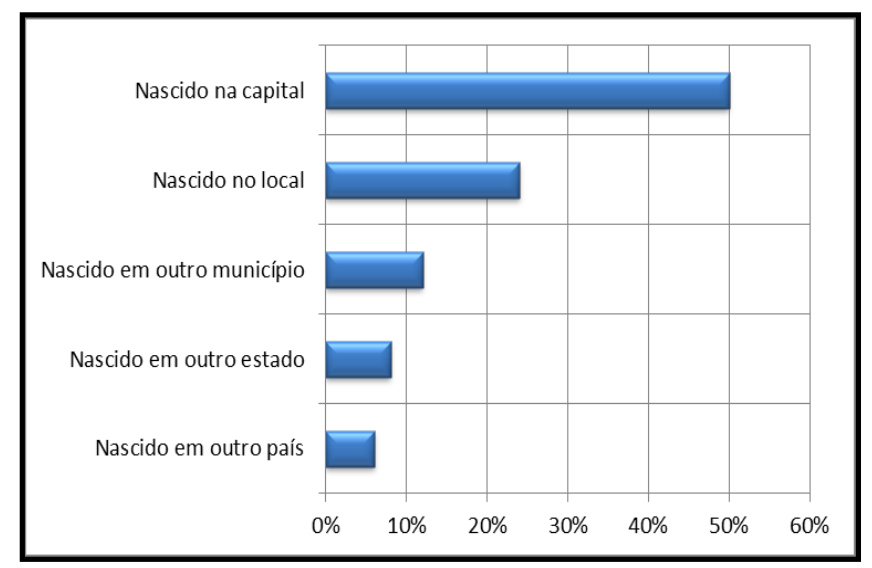

A grande representação de proprietários nascidos na capital fluminense reforça a tese de Graziano da Silva (1996) sobre a revalorização de atividades rurais não-agrícolas decorrentes das transformações do meio rural - que passa a ser lugar de moradia, de turismo, de lazer e de prestação de serviços -. Também as 
atividades relacionadas à preservação da natureza fazem parte deste processo. A dinâmica territorial e as práticas espaciais empreendidas pelos rppnistas corroboram a argumentação do autor supracitado.

A figura 12 a seguir destaca uma pequena diferença entre aqueles que declararam se o imóvel rural se enquadra ou não como residência principal. Além de o público pesquisado ser nascido e criado na capital fluminense, acrescenta-se que $52 \%$ dos informantes não são residentes fixos nas propriedades rurais, caracterizando-as principalmente como residências de veraneio e/ou, como os mesmos afirmam, de finalidade preservacionista.

Figura 12. Percentual de residentes fixos na propriedade rural. Fonte: GONÇALVES, 2019.

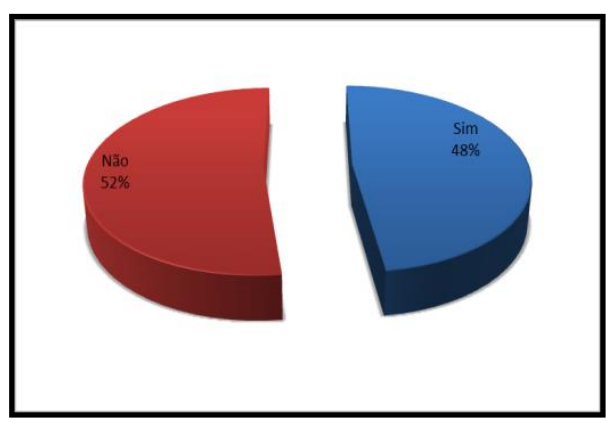

Ao analisarmos a figura 13 sobre o local de residência fixa dos informantes, identificamos que, além da capital fluminense, foram também citados outros municípios e a área central do mesmo município em que estão localizadas as propriedades rurais. Isso reforça que uma das características da ruralidade contemporânea é a idealização de uma aproximação e ressignificação da noção de natureza intrincada ao sistema urbano.

Figura 13. Local de residência fixa dos entrevistados. Fonte: GONÇALVES, 2019.

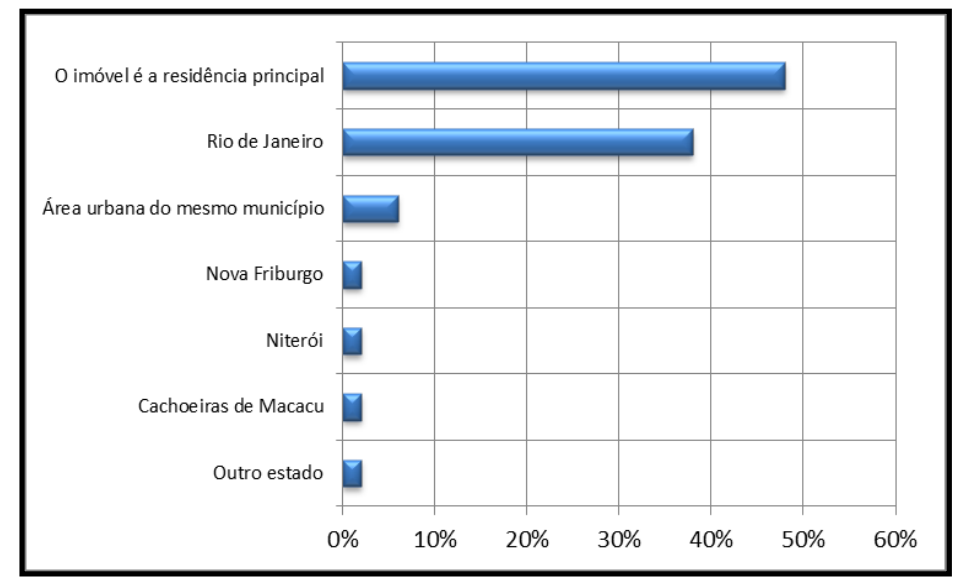


A figura 14 a seguir destaca os anseios característicos do padrão de ruralidade aqui em evidência e assentado na dimensão idílica da paisagem. Esse tipo de ruralidade, não mais calcada na produção, está orientada, de acordo com Graziano da Silva (1999), na busca dos homens por uma qualidade de vida que se perdeu na turbulência da vida nas cidades. Os projetos de empreendedorismo rural citados, nem sempre convertidos em rendimentos expressivos, caracterizam-se por hobbies ou projetos agropecuários de pequeno porte (modalidade tradicional e orgânica), turísticos, agroflorestais, silvícola e extrativista.

Figura 14. Motivos que justificaram o interesse dos entrevistados pela propriedade rural. Fonte: GONÇALVES, 2019.

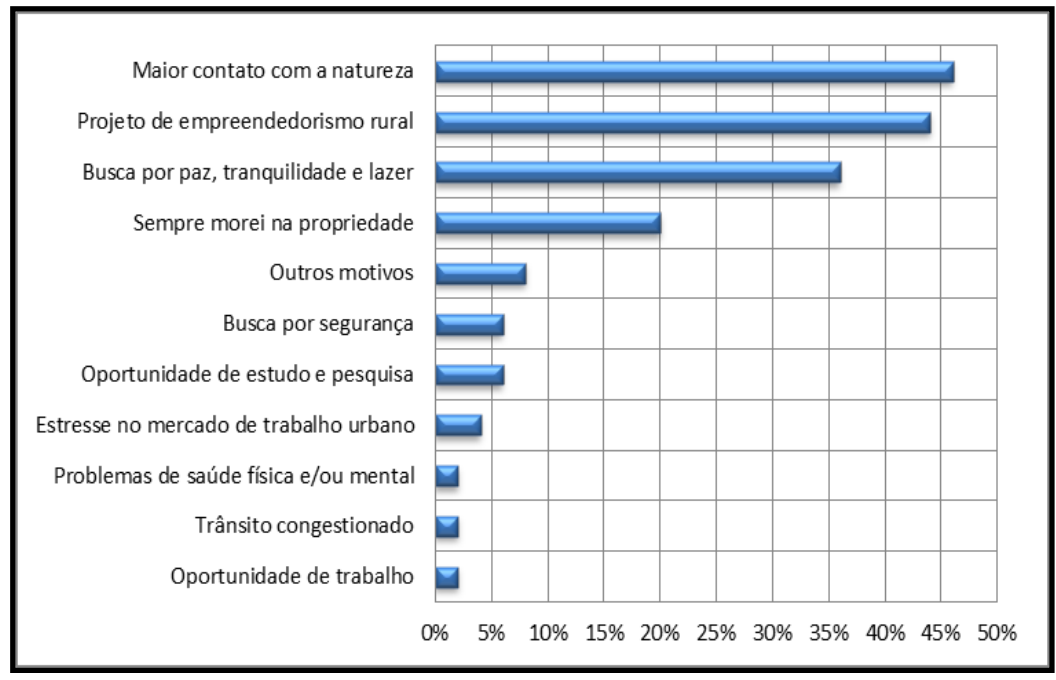

A seletividade espacial empregada na escolha de uma residência de veraneio, segundo o ponto de vista dos entrevistados, é a proximidade da metrópole, uma vez que $52 \%$ dos informantes não são residentes permanentes nas propriedades rurais. No entanto, esse critério também é válido para empreendimentos turísticos e agroecológicos, os quais também priorizam a proximidade de grandes centros urbanos para atrair consumidores.

Nesse contexto, como destaca Graziano da Silva (1999), o rural passa a ser almejado como ambiente para o lazer e para a "fuga dos problemas" da vida urbana, fazendo com que cresçam investimentos em condomínios horizontais, chácaras, hotéis-fazenda, spas, dentre outras modalidades. Conforme podemos analisar na figura 15 a seguir, o espaço rural se vê então, gradativamente, interpenetrado por outsiders, ou neorurais, grupo constituído por aposentados, profissionais liberais, amantes da natureza, muitos deles exmoradores ou ainda habitantes da cidade, que buscam no campo a idealização de tranquilidade e paz, mantidas, entretanto, as referências urbanas conectadas a verticalidades econômicas e socioculturais. 
Figura 15. Ocupação dos entrevistados. Fonte: GONÇALVES, 2019.

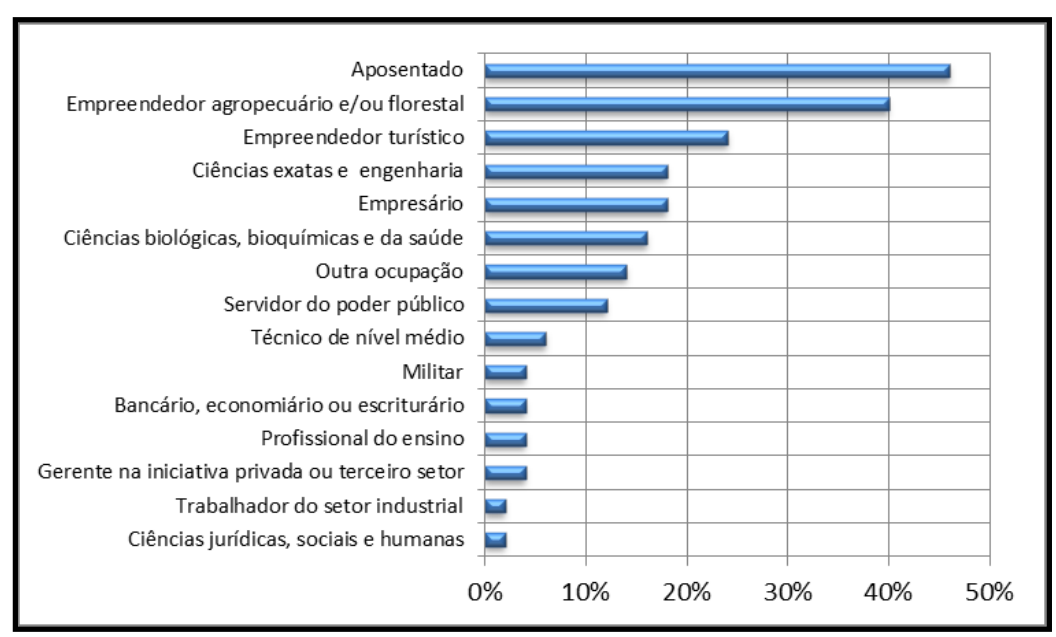

A figura 16 apresenta uma importante radiografia da dinâmica socioespacial no entorno das propriedades rurais visitadas. A partir de observações de campo, evidenciamos que a conversão de áreas para preservação tem avançado, predominantemente, em áreas onde áreas agrícolas tradicionais e de pecuária seguem em retração ou estagnadas.

Figura 16. Dinâmica de usos da terra no entorno das propriedades pesquisadas. Fonte: GONÇALVES, 2019.

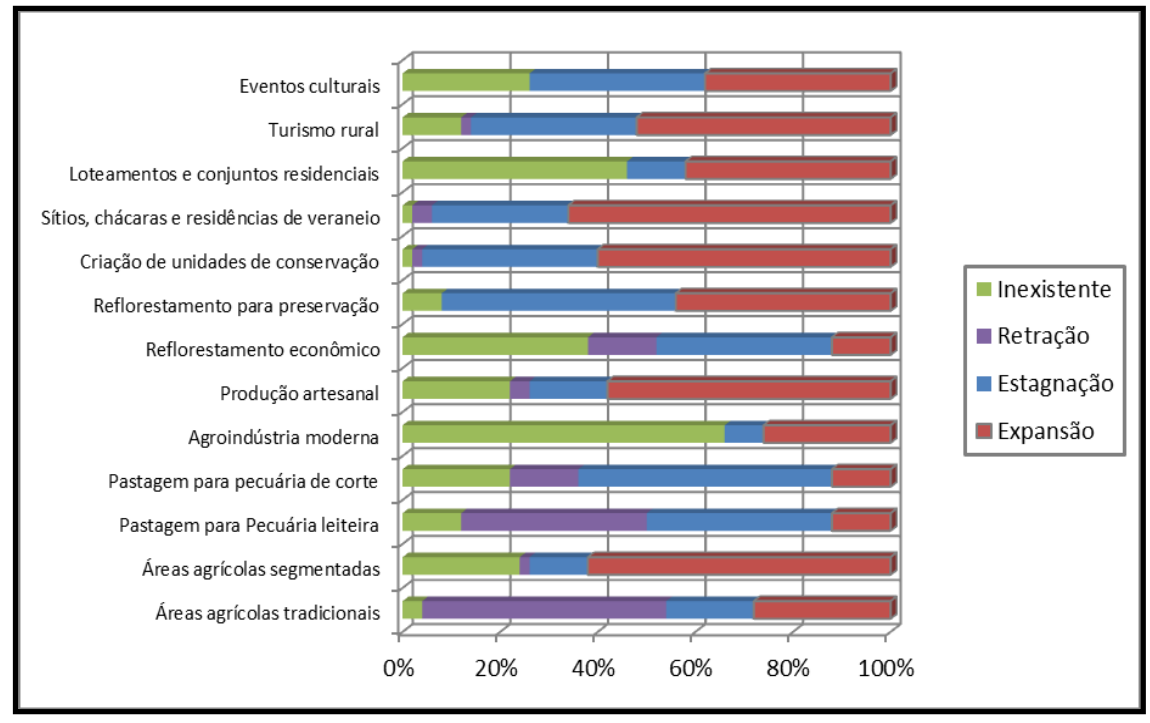

Paralelamente, sintomáticas de transformações socioespaciais e de reestruturação rural, observamos a expansão das seguintes categorias: turismo rural (ecoturismo); sítios, chácaras e residências de veraneio; criação de unidades de conservação; produção artesanal; e reflorestamento de áreas para preservação. A figura 17 abaixo exemplifica o avanço de residências de veraneio sobre áreas de pastagem na localidade 
Córrego da Luz, Casimiro de Abreu - RJ, próxima à rodovia RJ-142, que liga o referido município a Nova Friburgo - entorno viário identificado por expressiva concentração de RPPNs.

Figura 17. Avanço de residências de veraneio ao longo da RJ-142, Casimiro de Abreu/RJ. Fonte: GONÇALVES, 2019.

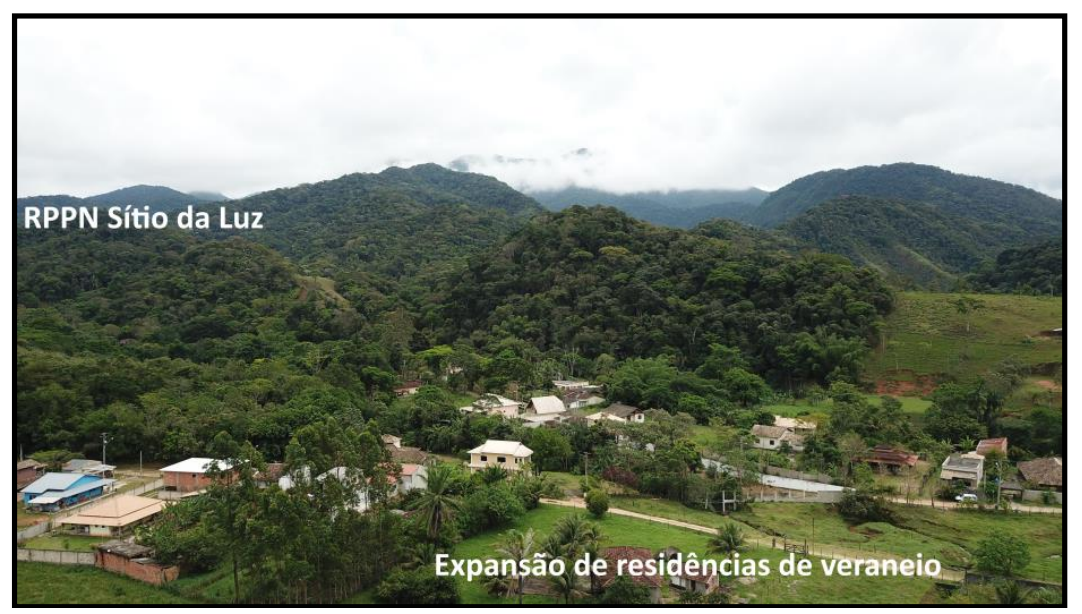

No entanto, esse padrão espacial não é o único registrado na amostragem pesquisada. Distancia-se da tendência de urbanização turística que acompanha a proliferação de reservas particulares exatamente aquelas regiões menos sujeitas aos efeitos da metropolização da capital fluminense.

Nesse sentido, cabe aqui particularizar - em termos de aderência do modelo RPPN ao mosaico agropecuário - aqueles municípios servidos de incentivos institucionais e financeiros, seja via repasse de ICMS ecológico ou Programas de PSA, como é o caso do Conexão Mata Atlântica em Varre-Sai-RJ, município representado por $1 / 5$ da amostragem pesquisada. Ao contrário do recuo de todas as atividades agropecuárias tradicionais, observamos, neste caso, a estagnação do plantel bovino, conjugado com a maior organização da atividade agrícola tradicional e orgânica em torno da produção cafeeira, a qual apresenta uma satisfatória infraestrutura de beneficiamento (secagem e torrefação).

Os resultados obtidos in loco apontaram para a incorporação - ao mosaico rural - de práticas conservacionistas representadas pela recomposição de APPs, delimitação de reservas legais e criação de RPPNs de menor dimensão, o que sugere ser essa experiência de atividades consorciadas mais recorrente em regiões mais distantes da região metropolitana. Neste caso, a densidade institucional foi decisiva para o sucesso do arranjo paisagístico multifuncional registrado em campo, o que não necessariamente dele exclui a incorporação de desenhos agroturísticos "de experiência” para consórcios futuros. A figura 18 ilustra a heterogeneidade espacial do cenário descrito. 
Figura 18. Mosaico agropecuário em propriedades rurais de Varre-Sai/RJ. Fonte: GONÇALVES, 2019.

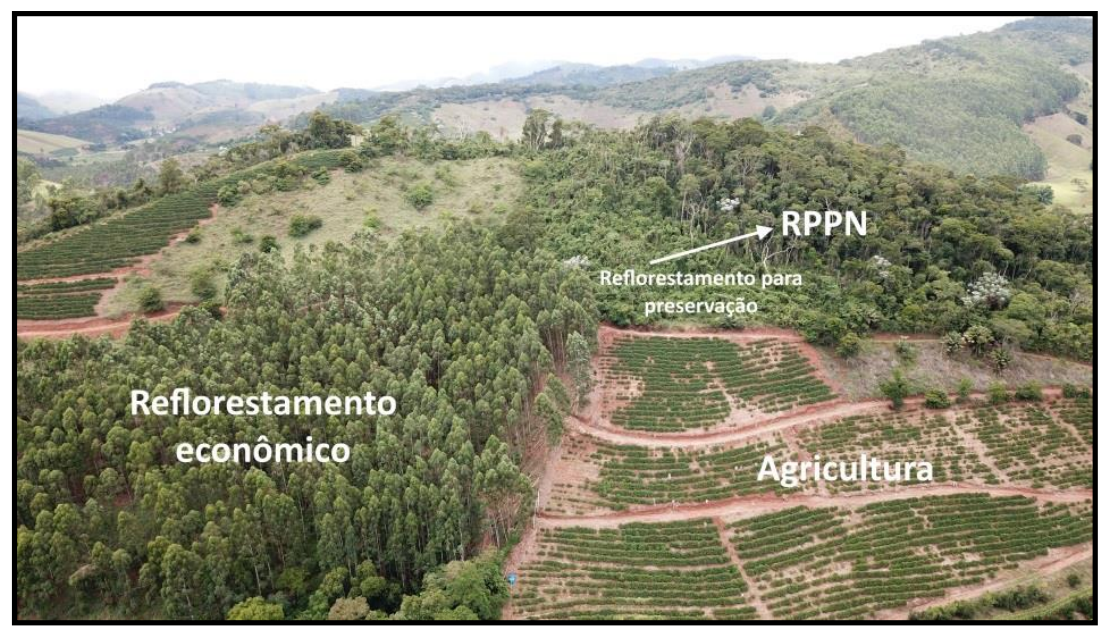

No que tange à existência de rendimentos oriundos dos imóveis rurais pesquisados, $60 \%$ da amostragem declarou desenvolver alguma atividade econômica nas propriedades e se enquadram, portanto, como produtores e/ou empreendedores rurais. Entretanto, $40 \%$ dos entrevistados estão inseridos socialmente como moradores rurais e afirmaram não possuir rendimentos na propriedade. Esse grupo corresponde a aposentados ou pensionistas com residência fixa, seguidos de veranistas. Tais dados reforçam a afirmação de Mesquita (2004, p.15-16) quando o autor descreveu o perfil dos proprietários de RPPN, composto, em sua maioria, por pessoas com certo grau de conscientização acerca da problemática ambiental e com recursos para se engajar em atividades preservacionistas, que pouco dependem da produção rural para compor suas rendas.

As figuras seguintes revelam que todos os entrevistados e/ou familiares possuem rendimentos externos à propriedade rural, representados por empregos urbanos, aposentadorias ou familiares inseridos em atividades terciárias no campo e/ou na cidade. Desses, 70\% afirmam que os rendimentos externos são superiores aos rendimentos oriundos exclusivamente das propriedades rurais.

Figuras 19 e 20. Existênca de rendimentos externos à propriedade rural. Fonte: GONÇALVES, 2019.

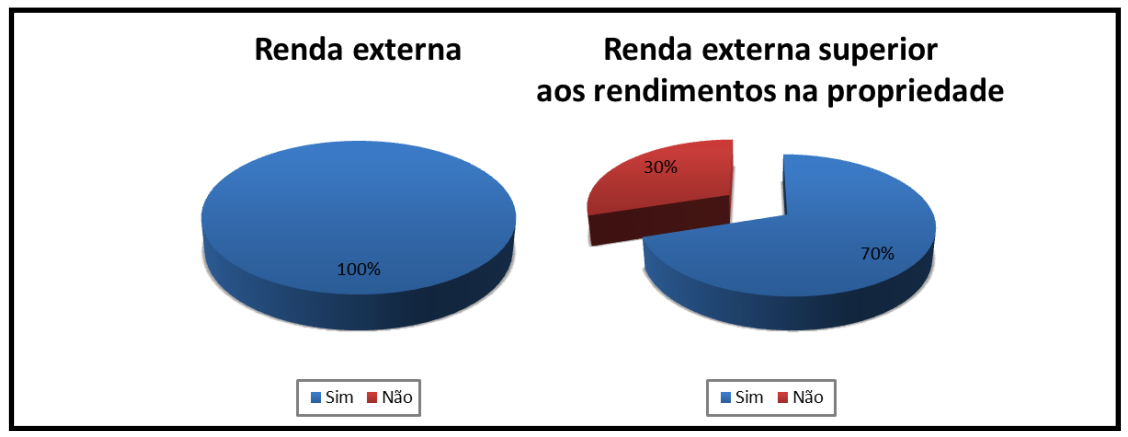


A justificativa para tal cenário é o fato de que, nas áreas sujeitas ao imperativo da metropolização e urbanização turística, a procura por terras é motivada pela valorização da natureza por segmentos de camadas médias urbanas que frequentam e retroalimentam um buffer de ressignificação rural no campo. De acordo com Carneiro e Teixeira (2012, p.80), tal valorização

é sustentada pela imagem da natureza intocada, expressa pela categoria mata - zona dominada pela vegetação que cresce espontaneamente. Se, para o agricultor, o espaço coberto de vegetação secundária é vislumbrado como uma lavoura em potencial e, portanto, qualificado de capoeira (por sua existência provisória e condicionada à plantação da lavoura), para os turistas, "novos rurais" e agentes ambientais, a mesma capoeira é vista como uma mata em regeneração.

Emerge daí uma nova hierarquia de valores em que a agricultura como forma de uso social da terra é colocada em posição secundária ou como representação pictória na paisagem. Observa-se, nesse sentido, um movimento no qual o avanço turístico e a busca por residências de veraneio estimulam o comércio local, contribuindo assim para ampliar a oferta de empregos aos membros das famílias de agricultores familiares, ao mesmo tempo em que desestimula a atividade agrícola ao deslocar mão-de-obra para o setor de serviços. (CARNEIRO e TEIXEIRA, 2012, p.81). A figura 21 detalha a miríade de funções assumidas nas propriedades dos rppnistas, ainda que $40 \%$ da amostragem tenha declarado a inexistência de rendimentos oriundos dos imóveis rurais.

Figura 21. Rendimentos gerados nas propriedades rurais com RPPN. Fonte: GONÇALVES, 2019.

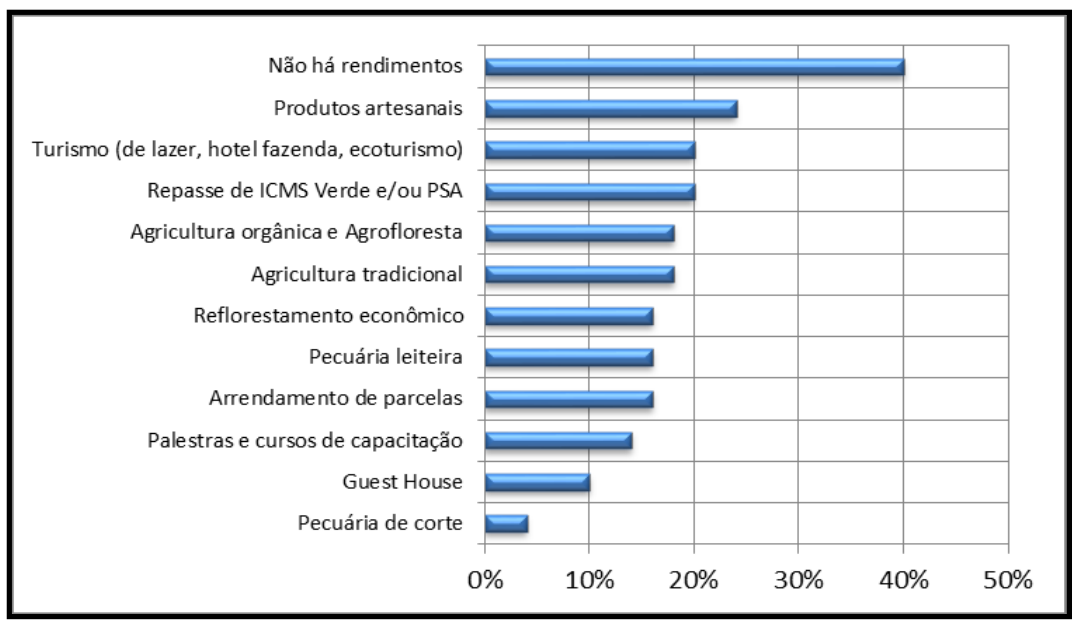

Os produtos artesanais que aparecem como entrada de divisas para pouco mais de $20 \%$ das propriedades incluem artigos alimentícios, como mel, banana passa, queijos, compostos fitoterápicos, repelentes naturais, licores, palmito pupunha, tomate seco em conserva, vinhos, pães e artigos decorativos. 
Em muitos casos, propriedades orientadas para o turismo revendem os referidos produtos com base no fornecimento e interação com proprietários rurais vizinhos. Pontualmente, foram também citados como fonte renda a comercialização de mudas de espécies da Mata Atlântica e de flores ornamentais. As divisas oriundas de repasses do ICMS ecológico e/ou Programas do tipo PSA estão circunscritas ao cluster de Varre-Sai-RJ, valendo aqui acrescentar casos representativos, porém, pouco explorados durante a pesquisa, no município de Rio Claro (área da RH Guandu), vinculado ao Programa Águas e Floresta (também alinhado à modalidade PSA).

De um modo geral, interessante é constatarmos que grande parte das atividades geradoras de renda nas propriedades com RPPN estão consorciadas e alinhadas ao paradigma pós-produtivista. Quando presentes, os rendimentos ligados a atividades não agrícolas sobressaem quanto à perspectiva de expansão, se comparados à pecuária de corte e leiteira, conforme é possível contatar ao analisarmos a figura 22.

Figura 22. Dinâmica das atividades desenvolvidas no interior das propriedades rurais. Fonte: GONÇALVES, 2019.

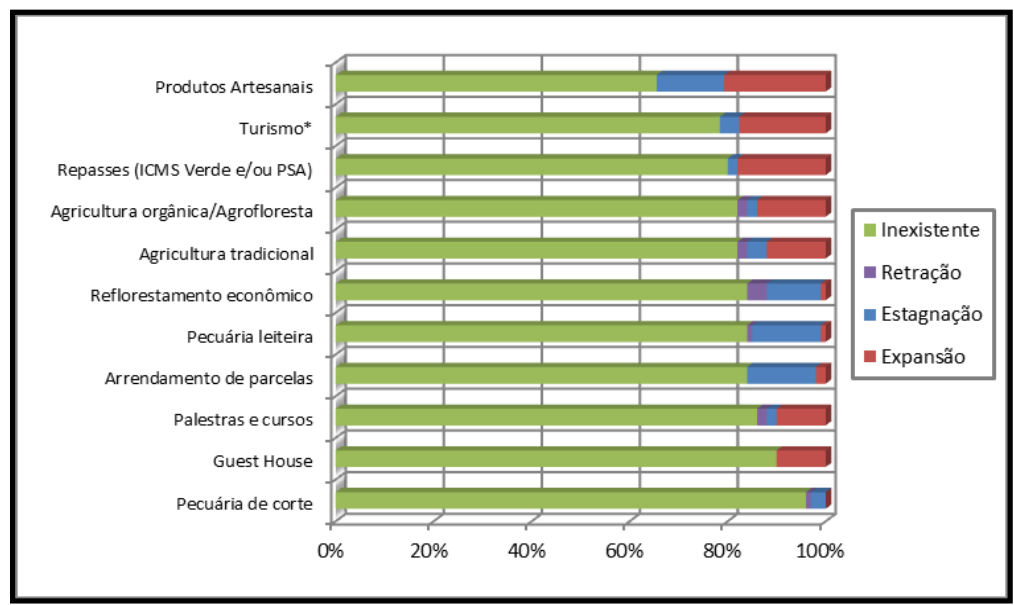

No entanto, o que realmente chama a atenção na figura anterior é a predominância da baixa expressividade das atividades agropecuárias e de serviços no conjunto amostral. Sobre a interpretação da figura 23, quando perguntados sobre a principal finalidade do imóvel rural, nos chamou a atenção que, mesmo naquelas propriedades com algum rendimento ligado a atividades agropecuárias e de serviços (produtos artesanais e turismo), os entrevistados afirmaram ser a função residencial o componente primeiro que secundariza - mas agrega - a dinâmica dos demais usos. Prevalece, nesse sentido, a noção de um território particular cujo acabamento e modelagem estão imbrincados de forte teor contraurbanizante. A noção de contraurbanização marca uma ruptura simbólica com a cidade, iniciando-se com ela uma nova fase de produção do espaço e de relações no âmbito de emergentes ruralidades. Até mesmo o grupo de veranistas 
ressalta que mais do que espaço de lazer e descanso, os imóveis cumprem a função primeira de preservação ambiental.

Figura 23. Função principal das propriedades visitadas. Fonte: GONÇALVES, 2019.

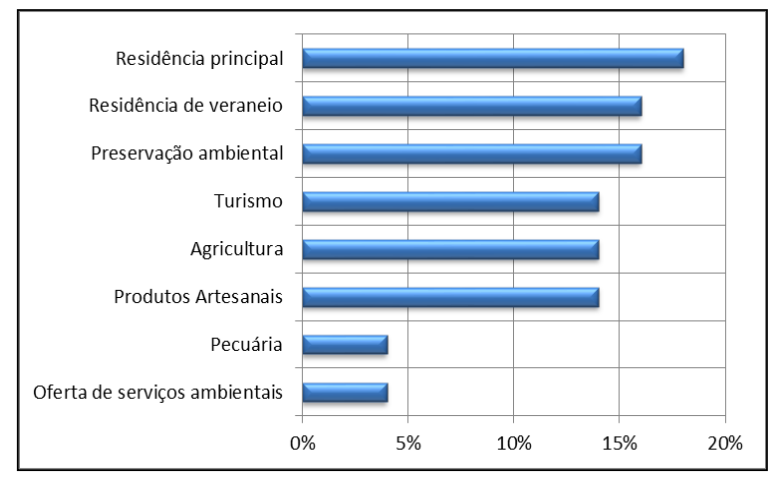

O gráfico anterior destacou como os rppnistas definiram a principal finalidade de suas propriedades. No entanto, essas funções não necessariamente se mantêm imutáveis ao longo do tempo, sendo redefinidas em função das práticas sociais empreendidas no substrato material. A ordem imaginada do discurso ambiental cimentou o desenho territorial das RPPNs e constituiu uma trama institucional produtora de uma noção de paisagem-natureza comodificada e patrimonializada, potencialmente aderente ao mosaico rural.

\section{CONSIDERAÇÕES FINAIS}

As RPPNs são espacialidades cuja dinâmica se manifesta a partir de práticas espaciais que refuncionalizam, ressignificam e se territorializam, revelando emergentes ruralidades. Nesse sentido, a paisagem derivada é, em concordância com Raffestin (2015), um desenho de esperança de quem a idealiza, seguida de uma expressão artística, transformando a percepção das formas da natureza em imagens que exprimem significados éticos, nutrindo possibilidades para viver esteticamente em harmonia paisagística de civilização e natureza.

Cabe acrescentar que a criação de unidades de conservação em propriedades rurais com perfil agropecuário consolidado também é uma realidade, ainda que menos recorrente. Esse grupo particular de rppnistas pode se tornar mais representativo em função da capilaridade normativa de ordenamento territorial e da institucionalização e efetividade de projetos voltados à adequação ambiental e iniciativas de remuneração por serviços ambientais.

Face à incipiência de políticas públicas mais integradas, plurais e efetivas para o território fluminense, o efeito centrífugo da metrópole e dos centros regionais no interior do estado sujeitam extensas áreas à expressiva especulação imobiliária - em 'pousio social' - que reforçam a marcante subutilização de seu espaço 
rural. Portanto, a emergência de dinâmicas urbano-rurais especificamente relacionadas com a criação de unidades de conservação particulares demanda leituras analíticas reveladoras da potencialidade de arranjos espaciais de preservação ambiental em sinergia com a diversificação de serviços no mosaico rural.

\section{REFERÊNCIAS}

CARNEIRO, M. J. Do "rural” como categoria de pensamento e como categoria analítica. In: CARNEIRO, M. J. (Org.). Ruralidades contemporâneas: modos de viver e pensar o rural na sociedade brasileira. Rio de Janeiro: Mauad X/ FAPERJ, 2012.

CARNEIRO, M. J. ; TEIXEIRA, V. L.. Para além das dualidades: o rural não agrícola no estado do Rio de Janeiro. In: CARNEIRO, M. J. (Org.). Ruralidades contemporâneas: modos de viver e pensar o rural na sociedade brasileira. Rio de Janeiro: Mauad X/ FAPERJ, 2012.

CORRÊA, R. L. Caminhos paralelos e entrecruzados. São Paulo: Editora UNESP, 2018.

GONÇALVES, E. S. Na trilha das Reservas Particulares do Patrimônio Natural (RPPN): dinâmicas territoriais produtoras de paisagens no estado do Rio de Janeiro. Tese (Doutorado em Geografia) - Departamento de Geografia e Meio Ambiente, Pontifícia Universidade Católica do Rio de Janeiro, p. 277. 2019.

GRAZIANO-DA-SILVA, J. A nova dinâmica da agricultura brasileira. Campinas: Unicamp-Instituto de Economia, 1996.

GRAZIANO-DA-SILVA, J. O novo rural brasileiro. 2. ed. Campinas: Unicamp-IE, 1999.

MARAFON, G. J. Permanências e mudanças no campo: transformações no espaço rural fluminense. In: SANTOS, A. M. S. P. ; MARAFON, G. J. ; SANT'ANNA, M. J. G. (orgs) Rio de Janeiro: um olhar socioespacial. Rio de Janeiro: Gramma, 2010.

MESQUITA, C. A. B. RPPN da Mata Atlântica: um olhar sobre as reservas particulares dos corredores de biodiversidade Central e da Serra do Mar. Belo Horizonte: Conservação Internacional, 2004.

OJIDOS, F. Conservação em ciclo contínuo: como gerar recursos com a natureza e garantir a sustentabilidade financeira de RPPNs. São Paulo: Essential Idea Editora, 2018.

RAFFESTIN, C. A produção das estruturas territoriais e sua representação. In: SAQUET, M. A. ; SPOSITO, E. S. (orgs.) Territórios e territorialidades: teorias, processos e conflitos. Rio de Janeiro: Consequência Editora, 2015.

SOUZA, M. L. Os conceitos fundamentais da pesquisa sócio-espacial. Rio de Janeiro: Bertrand, 2013. 